\title{
Effect of Different Seed Priming Methods on Germination and Vigour of Kabuli Chickpea (Cicer kabulium L.) Seeds
}

\author{
S. Ameer Sohail*, A.K. Chaurasia and Bineeta M. Bara
}

Department of Genetics and Plant Breeding, Naini Agricultural Institute, Sam Higginbottom University of Agriculture, Technology and Sciences, Allahabad, 211007 U.P., India

*Corresponding author

\begin{tabular}{|l|}
\hline K e y w o r d s \\
$\begin{array}{l}\text { Kabuli chickpea (Cicer } \\
\text { kabulium } \text { L.), Methods of } \\
\text { priming, Hydropriming, }\end{array}$ \\
$\begin{array}{l}\text { Osmopriming, Organic } \\
\text { priming, PEG } \text { Prooo, }_{\text {kcl, }} \\
\text { Neem leaf extract }\end{array}$ \\
\hline Article Info \\
\hline $\begin{array}{l}\text { Accepted: } \\
\text { 10 July 2018 } \\
\text { Available Online: } \\
\text { 10 August } 2018\end{array}$ \\
\hline
\end{tabular}

\section{A B S T R A C T}

The experiment was conducted in Post Graduate Laboratory and Field Experimentation Centre of Department of Genetics and Plant Breeding, Sam Higginbottom University of Agriculture, Technology and sciences, Allahabad (U.P.)during Rabi 2017-18 in order to standardize the best method of priming viz., hydropriming, halopriming, osmopriming and organic priming evaluated by screening a range of duration concentrations viz., T0Untreated (Control), T1-Distilled water (hydration), T2-Potassium chloride (KCL) (1\%), T3-Potassium chloride (KCL) 2\%, T4-polyethylene Glycol ( $\left.\mathrm{PEG}_{6000}\right) 1 \%$, T5polyethylene Glycol $\left(\mathrm{PEG}_{6000}\right)$ 2\%, and T6- Neem Leaf Extract 5\% for 8hours. It was found that all the priming methods showed significance difference with the control and the highest germination \% speed of germination, root length, shoot length, seedling length, fresh weight, dry weight, vigour index-I and vigour index-II. It was observed for $\mathrm{PEG}_{6000}$ best priming method. The Highest were observed in PEG and Neem leaf extract. In their solutions seeds priming for 8 hours and then dried for 24 hours in shade. This study Showed that seed priming Could improve some germination parameters in kabuli chickpea seed priming, its simplicity no requirements for extensive equipment and chemicals could be used method for overcoming problems related to a poor germination and seedling character, growth and vigour and with the help of seed priming treatments which are cost effective, economic, non-toxic and from eco-friendly sources.

\section{Introduction}

Kabuli Chickpea or white gram (Cicer kabulium L.); IN this group the colour of the seed is usually white grains are bold and attractive. Yield potential of this group is poor as compared to Desi or brown gram. Plants are generally taller than the Desi gram stand more or less erect. The chromosome number is $(2 \mathrm{n}=2 \mathrm{x}=16) \quad$ Chickpea, (Cicer kablium), belongs to genus Cicer, tribe cicereae, and is a member of the legume, pea, or pulse family, "Fabaceae" and subfamily Papilionacea (Singh et al., 1997).

It also called leguminosae, this family of flowering plants is one the largest plant families and include such important plants as beans, peas, peanuts, lupines, alfalfa, clover, and acacia, and many others. Chickpea is highly self-pollinated leguminous crop that ranks second in area and third in production 
among the pulses. Chickpea is the common name for an annual plant. It widely cultivated for its typically yellow-brown, pea like seeds.

Chickpea is the third most important pulse crop in the world after beans and peas. It is cultivated on an area of 12 million hectares with 8.9 million tons of annual production. Chickpea plays an important role to improve soil fertility by fixing atmospheric nitrogen with the help of root nodules (Anabessa et al., 2006). Chickpea is native of south-eastern Turkey and Syria (Saxena and Singh, 1987). Chickpea is one of the important crops of Andhra Pradesh. Though small seeded (Desi) type has been popular, the bold seeded (Kabuli) type is gaining the farmers interest due to its better consumer preference and high market price. Kabuli chickpea (Cicer kabulium L.) has a good demand for consumption due to high nutritive value and fairly free from anti-nutritional value. The cultivation of kabuli chickpea is rapidly expanding in Prakasam district of Andhra Pradesh for the last 3 or 4 years by replacing tobacco, cotton and other commercial crops in view of their eroding profitability. The chickpea crop is mainly raised on residual soil moisture and available relative humidity during winter season. The productivity of kabuli chickpea is poor, which may be attributed to the limited adoption of improved cultivation techniques and imbalanced nutrition. Among pulses, for production, chickpea occupies the first position in India and third position at global level (FAO, 2012).

The general purpose of seed priming is to partially hydrate the seed to appoint where germination processes are begun but not completed. Treated seeds whit soaking in water (Hydropriming), Soaking in inorganic salt solutions (Halo priming) and different leaf extract(organic priming), osmotic stress (Osmopriming) are usually redried before use, but they would exhibit rapid germination when re-imbibed under normal or stress conditions. Each treatment may have varying effects depending upon plant species, stage of plant development, concentration/dose of priming agent, and incubation period (Ashraf et al., 2005).

\section{Materials and Methods}

The experiment was conducted in Post Graduate Laboratory, Department of Genetics and Plant Breeding, Sam Higginbottom University of Agriculture, Technology and Sciences, Allahabad (U.P.) in order to standardize the best method of priming specific to Kabuli chickpea (var. Ujjawal). The treatments used at different concentrations for priming were, TOunprimed (control), T1-Distilled water hydration for 8 (hrs) T2-Potassium chloride (KCL) 1\% T3-Potassium chloride (KCL) 2\%, T4-Polyethylene Glycol (PEG) 6000 1\%, T5Polyethylene Glycol (PEG) 6000 2\%, T6-Neem leaf extract $5 \%$ for $8 \mathrm{hrs}$. After cleaning and grading, the seeds were soaked in respective priming solutions at different volume of seeds for twelve hours. Then the seeds were air dried under the shade to bring back to their original moisture content and used for sowing on laboratory. Hundred seeds of each treatment were placed for germination in four Replications in Complete Randomized Design (CRD). The between paper method used for samples and place for germination in germination chamber al $25{ }^{\circ} \mathrm{C}$ temperature. Germination parameters were Germination Percentage (\%), Speed of germination, Root length $(\mathrm{cm})$, Shoot length $(\mathrm{cm})$, Seedling length $(\mathrm{cm})$, Fresh weight of seedling $(\mathrm{g})$, Dry weight of seedling $(\mathrm{g})$, Seed vigour index I and Seed vigour index II.

\section{Preparation of solutions}

For the preparation of solution one gram of each chemical was taken in a beaker. These 
chemicals were added separately in $1000 \mathrm{ml}$. of distilled water with constant stirring. The volume of solution will finally constitute to one litter, and then it becomes 1000 ppm stock solution of each chemical.

The flasks containing chemicals was covered with muslin cloth to avoid any contamination For the preparation of $\mathrm{KCl} 1 \%$ solution $10(\mathrm{~g})$, $\mathrm{KCl} 2 \%$ solution $20(\mathrm{~g})$, was taken in a measuring flask made up to $100 \mathrm{ml}$. Distilled water while for PEG 1\% solution 10(g). PEG $2 \%$ solution $20(\mathrm{~g})$.

Neem leaf extract (5\%) solution $50(\mathrm{ml})$ was taken in measuring flask and made up to 100 $\mathrm{ml}$ with distilled water.

\section{Preparation of plant leaf extract}

The fresh neem leaves were collected separately and dried in shade. The shade dried leaves were powdered using mortar and pestle.

Then exactly weight fifty gram of leaf powder using weighing balance and dissolved in 100 $\mathrm{ml}$. of distilled water which was measured already in the beaker to make $5 \%$ leaf extract.

The leaf extract was filtered by using muslin cloth to remove unwanted material and leaf debris.

\section{Results and Discussion}

\section{Analysis of variance}

The analysis of variance for seedling characters was presented in Table 1. Analysis of variance revealed that the differences among seven treatments were significant for seedling characters, viz., germination per cent, speed of germination, root length, shoot length, seedling length, seedling fresh weight, seedling dry weight, seed vigour index I and seed vigour index II.

\section{Mean performance}

The data presented in the table showed mean performance and range of 7 treatments for 9 seed quality parameters in table 2 .

\section{Germination (\%)}

The date range of germination percentage was observed from 76.00 to 88.00 with mean value of 81.51. Maximum highest percentage of germination (88.00) was reported in $\mathrm{T}_{5}$ PEG $2 \%$ and it was followed by $\mathrm{T}_{4}(84.29)$ with Treatment of PEG $1 \%$.

Minimum germination percentage was recorded by $\mathrm{T}_{0}$ (76.00) with control. These are similar finding results reported by Bradford (2002), Ashraf and Foolad (2005), Muhammad Arif et al., (2008), Kaya et al., (2008) and Ghassemi-Golezani et al., (2010).

\section{Speed of germination}

The date range of speed of germination was from 67.88 to 84.13 with mean value of 72.34 .

Maximum speed of germination (84.13.) was reported in $\mathrm{T}_{5}$ PEG $2 \%$ and it was followed by $\mathrm{T}_{4}$ (82.63) with Treatment of PEG $1 \%$. Minimum speed of germination was recorded by $\mathrm{T}_{0}(67.88)$ with control.

These are similar finding results reported by Cantliffee (1981), Basra et al., (2003), Kaya et al., (2008) and Iqbal Hussain et al., (2015).

\section{Root length (cm)}

The data range of seedling root length 11.69 $\mathrm{cm}$ to $18.39 \mathrm{~cm}$. with mean value of $15.25 \mathrm{~cm}$. Maximum root length $(18.39 \mathrm{~cm})$ was recorded by $\mathrm{T}_{5}$ with Treatment of PEG $2 \%$ and it was followed by $\mathrm{T}_{4}(18.11 \mathrm{~cm})$ with Treatment of PEG 1\%. Minimum root length was recorded by $\mathrm{T}_{0}(11.69 \mathrm{~cm})$ with control. 
Table.1 Analysis of variance for 9 seedling characters in Kabuli chickpea

\begin{tabular}{|c|c|c|c|}
\hline \multirow[t]{2}{*}{ S. no } & \multirow[t]{2}{*}{ Characters } & \multicolumn{2}{|c|}{ Mean sum of squares } \\
\hline & & Treatments $(\mathrm{df}=6)$ & Error $(\mathrm{df}=21)$ \\
\hline 1. & Germination \% & $61.8831 * *$ & 0.8369 \\
\hline 2 & Speed of germination & $159.5133 * *$ & 0.5342 \\
\hline 3 & Root length & $25.3238 * *$ & 0.3117 \\
\hline 4. & Shoot length & $25.4048 * *$ & 0.1296 \\
\hline 5. & Seedling length & $100.6943 * *$ & 0.4308 \\
\hline 6 & Seedling fresh weight & $3.1392 * *$ & 0.0048 \\
\hline 7 & Seedling dry weight & $0.2151 * *$ & 0.0008 \\
\hline 8. & Seed vigour index $-\mathrm{I}$ & $1063644.28 * *$ & 325616.5391 \\
\hline 9. & Seed vigour index - II & $2632.0599 * *$ & 3.3370 \\
\hline
\end{tabular}

$* \& * *$ Significant at $1 \%$ and $5 \%$ level of significance respectively.

Table.2 Mean performance of chickpea for 9 seedling characters

\begin{tabular}{|c|c|c|c|c|c|c|c|c|c|c|}
\hline S.NO. & Treatments & $\begin{array}{c}\text { Germination } \\
(\%)\end{array}$ & $\begin{array}{c}\text { Speed of } \\
\text { germination }\end{array}$ & $\begin{array}{c}\text { Root } \\
\text { length }(\mathrm{cm})\end{array}$ & $\begin{array}{l}\text { Shoot } \\
\text { Length } \\
\text { (cm) }\end{array}$ & $\begin{array}{c}\text { Seedling } \\
\text { Length }(\mathbf{c m})\end{array}$ & $\begin{array}{c}\text { Fresh } \\
\text { Weight of } \\
\text { Seedling } \\
\text { (gm) }\end{array}$ & $\begin{array}{l}\text { Dry Weight } \\
\text { of Seedling } \\
\text { (mg) }\end{array}$ & $\begin{array}{c}\text { Seed } \\
\text { Vigour } \\
\text { Index-I }\end{array}$ & $\begin{array}{c}\text { Seed } \\
\text { Vigour } \\
\text { Index -II }\end{array}$ \\
\hline 1 & $\mathbf{T}_{\mathbf{0}}$ & 76.00 & 67.88 & 11.69 & 17.80 & 29.49 & 5.01 & 1.39 & 2182.24 & 105.45 \\
\hline 2 & $\mathbf{T}_{1}$ & 78.63 & 71.69 & 13.01 & 19.39 & 32.49 & 6.23 & 1.55 & 2492.64 & 121.85 \\
\hline 3 & $\mathbf{T}_{2}$ & 79.69 & 72.71 & 14.02 & 20.52 & 34.91 & 6.44 & 1.65 & 2719.85 & 131.85 \\
\hline 4 & $\mathbf{T}_{3}$ & 81.44 & 73.88 & 15.07 & 21.68 & 36.75 & 6.71 & 1.73 & 2944.92 & 140.69 \\
\hline 5 & $\mathbf{T}_{4}$ & 84.29 & 82.63 & 18.11 & 23.87 & 41.99 & 7.17 & 1.96 & 3540.13 & 165.33 \\
\hline 6 & $\mathbf{T}_{5}$ & 88.00 & 84.13 & 18.39 & 24.91 & 43.90 & 7.87 & 2.05 & 3773.91 & 179.96 \\
\hline 7 & $\mathrm{~T}_{6}$ & 82.50 & 81.50 & 16.30 & 22.84 & 39.14 & 6.86 & 1.85 & 3212.37 & 152.41 \\
\hline \multicolumn{2}{|c|}{ Grand Mean } & 81.51 & 76.34 & 15.25 & 21.57 & 36.85 & 6.61 & 1.74 & 2980.866 & 142.45 \\
\hline \multicolumn{2}{|c|}{ C.D. $(5 \%)$} & 1.371 & 1.096 & 0.837 & 0.540 & 0.984 & 0.104 & 0.041 & 855.410 & 2.738 \\
\hline \multicolumn{2}{|c|}{$\mathrm{SEd}(\mathrm{m})$} & 0.647 & 0.517 & 0.395 & 0.255 & 0.464 & 0.049 & 0.019 & 403.495 & 1.292 \\
\hline \multicolumn{2}{|c|}{ C.V. } & 0.040 & 0.034 & 0.131 & 0.060 & 0.064 & 0.038 & 0.057 & 0.711 & 0.046 \\
\hline
\end{tabular}


Int.J.Curr.Microbiol.App.Sci (2018) 7(8): 1396-1404

Fig.1 Mean performance of chickpea for 9 seedling characters

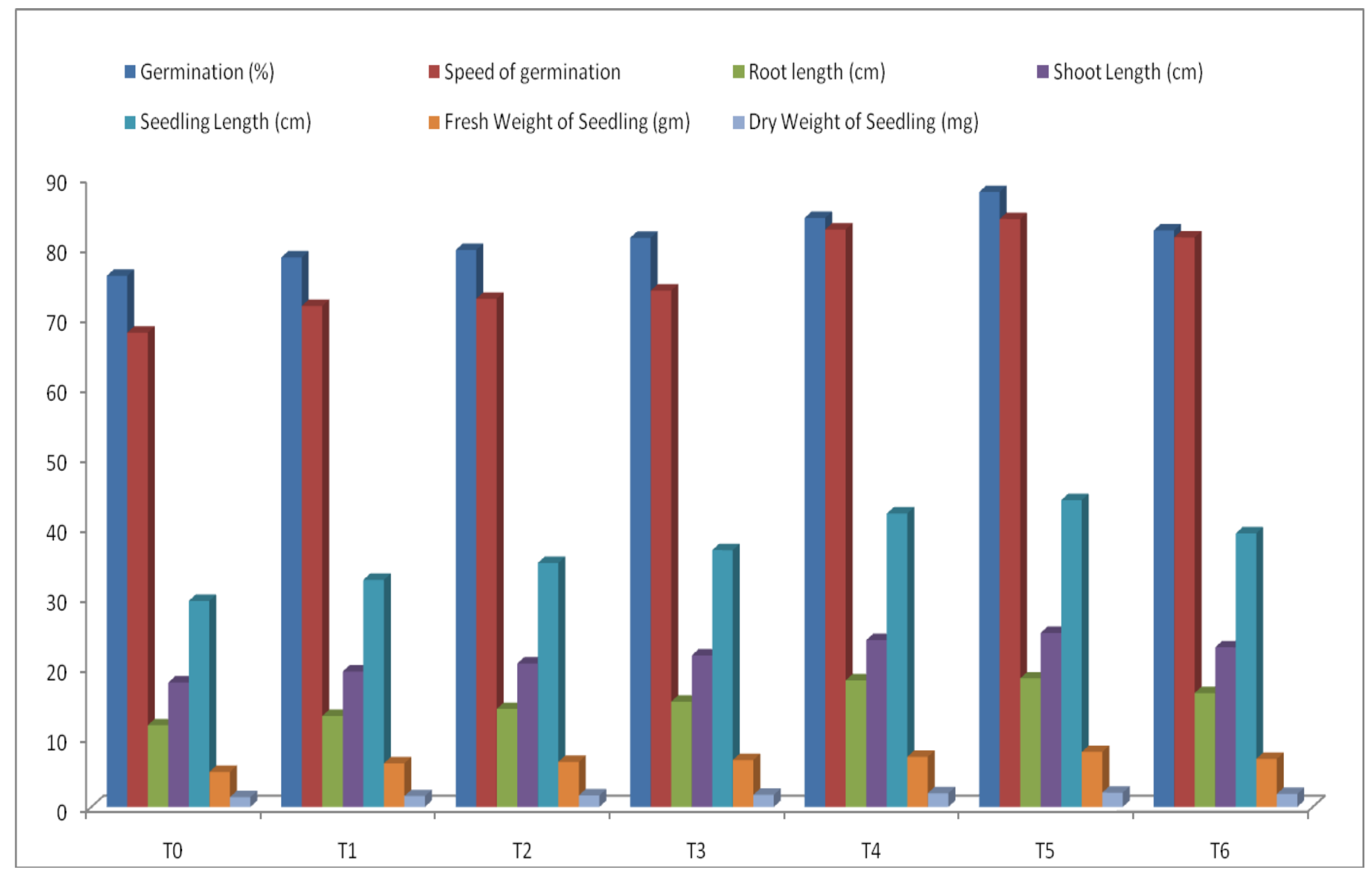


Fig.2 Effect of priming on seed vigour index I \& II

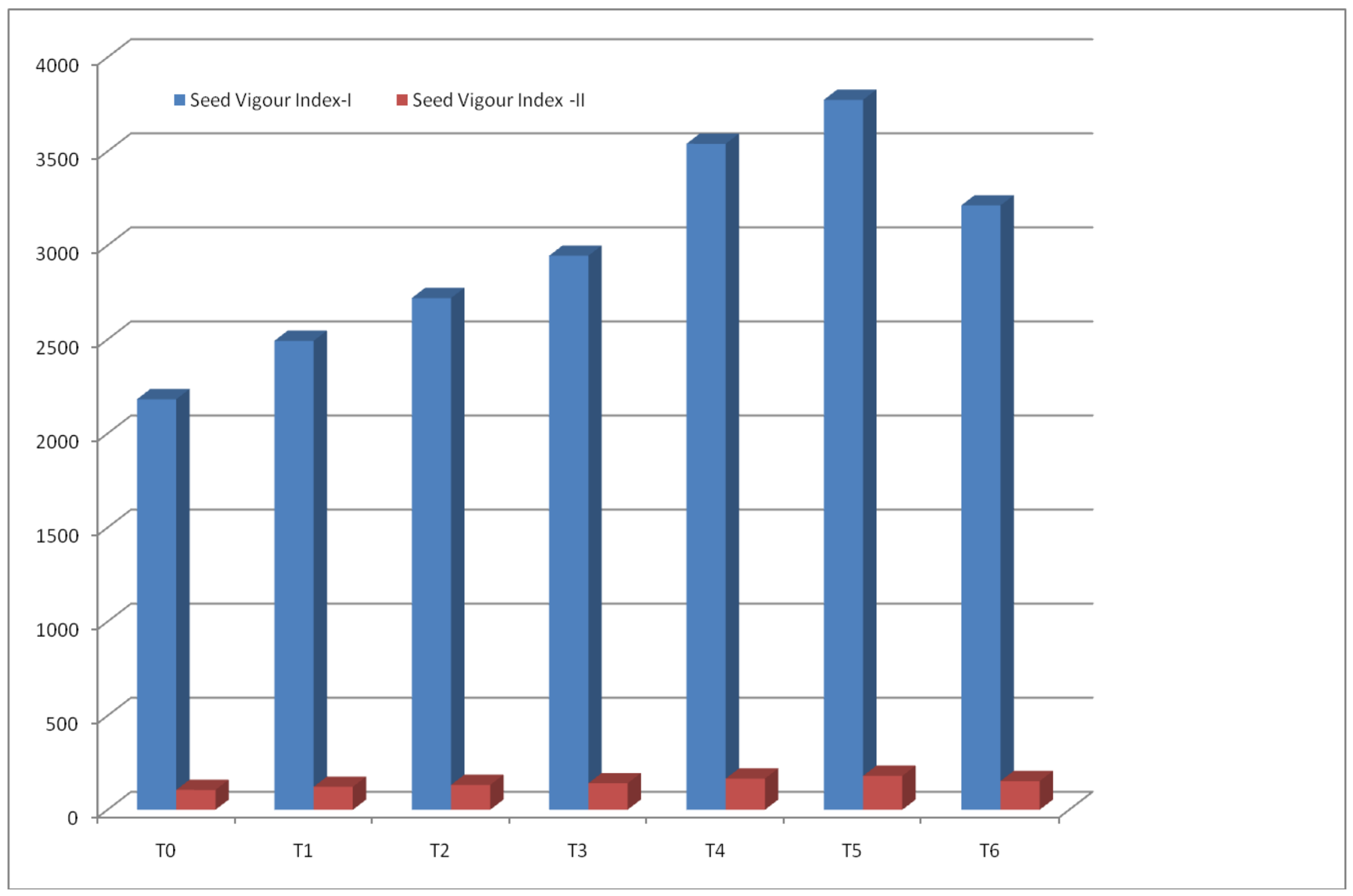


These are similar finding results reported by Farooq et al., (2006), Mavi et al., (2006), Pallais (2006), Venkatasubramanian and Umarani (2007) and Kaya et al., (2008).

\section{Shoot length (cm)}

The data range of seedling shoot length from $17.80 \mathrm{~cm}$ to $24.91 \mathrm{~cm}$. with mean value of $21.57 \mathrm{~cm}$. Maximum shoot length $(24 . .91 \mathrm{~cm})$ was recorded by $\mathrm{T}_{4}$ with Treatment of PEG $2 \%$ and it was followed by $\mathrm{T}_{4}(23.87 \mathrm{~cm})$ with Treatment of PEG 1\%.The Minimum shoot length was recorded by $\mathrm{T}_{0}(17.80 \mathrm{~cm})$ with control. These are similar finding results reported by Farooq et al., (2006), Mavi et al., (2006), Pallais (2006), Venkatasubramanian and Umarani (2007) and Kaya et al., (2008).

\section{Seedling length $(\mathrm{cm})$}

The data range of seedling length $(\mathrm{cm})$ from $29.49 \mathrm{~cm}$ to $43.30 \mathrm{~cm}$. with mean value of $36.85 \mathrm{~cm}$. Maximum seedling length $(43.30 \mathrm{~cm})$ was recorded by $\mathrm{T}_{5}$ with Treatment of PEG $2 \%$ and it was followed by $\mathrm{T}_{4}$ $(41.99 \mathrm{~cm})$ with Treatment of PEG $1 \%$. Minimum seedling length was recorded by $\mathrm{T}_{0}$ $(29.49 \mathrm{~cm})$ with control. These are similar finding results reported by Harris et al., (2001), Rashid et al., (2005), Arif et al., (2005), Kaya et al., (2008) and Maroufi et al., (2011).

\section{Fresh weight (mg)}

The data range of seedling fresh weight is from $5.01 \mathrm{gm}$ to $7.87 \mathrm{gm}$. with mean value of $6.61 \mathrm{gm}$. Maximum seedling fresh weight (7.87 gm) was recorded by $T_{5}$ with Treatment of PEG2\% and it was followed by $\mathrm{T}_{4}(7.17$ gm) with Treatment of PEG 1\%. Minimum seedling fresh weight was recorded by $\mathrm{T}_{0}$ $(5.01 \mathrm{gm})$ with control. These are similar finding results reported by Farooq et al., (2006), Singh et al., (2004), (2005), Kaya et al., (2008) Mehtra et al., (2010) and Chavan et al., (2014).

\section{Dry weight (mg)}

The data range of seedling dry weight from $1.39 \mathrm{gm}$ to $2.05 \mathrm{mg}$. with mean value of $1.74 \mathrm{mg}$. Maximum seedling fresh weight ( $2.05 \mathrm{mg}$ ) was recorded by $\mathrm{T}_{5}$ with Treatment of PEG2\% and it was followed by $\mathrm{T}_{4}$ $(1.96 \mathrm{gm})$ with Treatment of PEG $1 \%$. Minimum value of seedling fresh weight was recorded by $\mathrm{T}_{0}(1.39 \mathrm{gm})$ with control. These are similar finding results reported by Nagar et al., (1998), Mehtra et al., (2010), Rao et al., (1987) and Chavan et al., (2014).

\section{Seed vigour index - I}

The data range of seedling vigour index length 2182.24from 3773.91.with mean value of 2980.866. Maximum seedling vigour index length (3773.91) was recorded by $\mathrm{T}_{5}$ with Treatment of PEG 2\% and it was followed by $\mathrm{T}_{4}$ (3540.13) with Treatment of PEG1\%. Minimum seedling vigour index length was recorded by $\mathrm{T}_{0}$ (2182.24) with control. These are similar finding results reported by Hassan Pouraghdam et al., (2009), Umair Adrian Ali et al., (2010), Umair et al., (2013), Ambika and Balakrishnan (2015), Parmar et al., (2016) and Khan (2017).

\section{Seed vigour index -II}

The data range of seedling seed vigour index mass from 105.45 to 179.96 . with mean value of 142.45 Maximum seedling vigour index mass (179.96) was recorded by $\mathrm{T}_{5}$ with Treatment of PEG $2 \%$ and it was followed by $\mathrm{T}_{4}$ (165.33) with Treatment of PEG $1 \%$.Minimum seedling vigour index mass was recorded by $\mathrm{T}_{0}$ (105.45) with control. These are similar finding results reported by Pallais (2006), Venkatasubramanian and Umarani (2007), Mohamed and Hannachi (2012), 
Ambika and Balakrishnan (2015), Parmar et al., (2016) and Khan (2017).

On the basis of result obtained from the present experiment, following conclusions are drawn. Among all the seed priming treatments, seed priming with PEG 6000 (osmo priming) was found to be the best priming treatment followed by organic priming. Among all seed priming treatments PEG 2\% having more pronounced effect on germination behavior and vigour in kabuli chickpea seeds.

\section{Acknowledgement}

The author are thankful to the Hon'ble Vice Chancellor, HOD, Advisor and non-Teaching staff Department of Genetics and Plant Breeding, Sam Higginbottom University of Agriculture, Technology and Science Allahabad, U. P., for providing all necessary facilities and support.

\section{References}

Abdul-Baki, A.A. and Anderson, J.D. (1973). Vigour determination in soybean seeds by multiple criteria. Crop Science. 13: PP 630-633.

Ambika S. and Balakrishnan K. (2015). Enhancing germination and seedling vigour in cluster bean by organic priming. Department of Seed Science and Technology, Agricultural College and Research Institute, Madurai- 625 104, India.

Ashraf, M. and M. R. Foolad (2005). Presowing seed treatment: A shotgun approach to improve germination, plant growth and crop yield under saline and non-saline conditions. Advances in Agronomy, 88:223-271.

Basra, et al., (2003).Evaluation of seedling vigour of hydro and matri-primed wheat (Triticum aestivum L.) seeds. Int. J. Agric. Biol. 2:121-123.
Bradford et al., (2002). Seed priming influence on germination and emergence of pepper seed lots. Crop Science, 30: PP 718-721.

Cantliffe, D.J., (1981). Seed priming of lettuce for early and uniform emergence under conditions of environmental stress. Acta Horticulture, 122: PP 29-38.

Chavan, et al., (2014). Effect of Seed Priming on Field Performance and Seed Yield of Soybean [Glycine Max (L.) Merill] Varieties. The Bioscan, 9 (1): 111-114.

FAO (2012). http://faostat.fao.org/default.aspx December, 2010 to March, 2011.

Farooq, et al., (2006). Boron nutripriming improves the germination and early seedling growth of rice (Oryza sativa L.). Journal of Plant Nutrition, 34: 15071515.

Ghassemi-Golezani, et al., (2008a). Effects of different priming techniques on seed invigoration and seedling establishment of lentil (Lens culinaris Medik). J. Food. Agri. Environ. 6: 222-226.

Harris et al., (2001) opined that seed priming in wheat prior to sowing significantly improved germination and initial establishment under unfavourable conditions of marginal land.

Hassanpouraghdam, M.B., Pardaz, J.E. and Akhtar, N.F. (2009). The effect of osmopriming on germination and seedling growth of Brassica napus L. under salinity conditions. J. Food, Agriculture \& Environment 7: 620-622.

Heydecker, W. (1973). Accelerated germination by osmotic seed treatment. Nature. 246: 42-44.

International, Wallingford, Oxon., OX10 9DE, UK (1987), 127-162.

Iqbal, M. A., (2015). Improving Germination and Seedling Vigour of Cowpea (Vigna unguiculata L.) with Different Priming Techniques, American-Eurasian J. Agric. \& Environ. Sci., 15 (2): 265-270.

Kaya et al., (2008) reported that mean frequency of germination, germination time, germination index, root length, shoot length and seedling fresh weight 
showed seed size-dependent responses of cultivars to salt stress.

Khan (2017) his article describes about the various types of seed deterioration taking place and different priming techniques used to improve the vigour of normal as well as poor or deteriorated seeds.

Maroufi, K., Farahani, H. A. and Moradi, O. (2011). Increasing of seedling vigour by hydro priming method in cowpea (Vigna sinensis L.) Advanc.in Environ. Bio, 5(11): 3668-3671.

Mohamed Aymen Elouaer, Cherif Hannachi (2012), Seed priming to improve germination and seedling growth of safflower (Carthamus tinctorious) under salt stress, EurAsian Journal of Biosciences, 6: PP 76-84.

Moradi, A., and Younesi, O., (2009), Effects of osmo and hydropriming on seed parameters of grain sorghum (Sorghum bicolour L.) Australian Journal of Basic Application in Sciences 3(3): 1696-1700.

Pallais, N. (2006). Osmotic priming of true potato seeds. Effects of seed age. Plant Physiology, 32: 235-244.

Panse, V.G. and Sukhatme, P.V. (1967). Statistical methods for agricultural workers (2nd edn.) ICAR Publication, New Delhi.

Parmar R. K., M. J. Patel, R. M. Thakkar and T. Tsomu (2016). Influence of Seed Priming Treatments on Germination and Seedling Vigour of Custard Apple (Annona Squamosa L.) Cv. Local. An International Quarterly Journal Life Science, 11(1): PP 389-393.

Rashid et al., (2004) reported that overnight (8$12 \mathrm{~h})$ seed hydropriming improved germination, vigour and a good plant stand as well as reduced pest and disease in chickpea and mungbean.

Saxena, M.C. (1990). Problems and potential of chickpea production in the nineties.In Chickpea in the Nineties Production. Second International Workshop on Chickpea Improvement, ICRISAT Centre, Patancheru, Andhra Pradesh, India.

Saxena, M.C. and Singh, K.B. (1987). Chickpea Commonwealth Agricultural Bureaux.

Selvarani, K. and Umarani, R. (2011). Evaluation of seed priming methods to improve seed vigour of onion (Allium cepa cv. aggregatum) and carrot (Daucus carota). Journal of Agricultural Technology 7(3): 857-867

Singh, A., Dahiru, R., Musa, R., and Haliru, B. S., (2014). Effect of Osmopriming Duration on Germination, Emergence, and Early Growth of Cowpea (Vigna unguiculata (L.) Walp.), In the Sudan Savanna of Nigeria. International Journal of Agronomy Volume 2014, Article ID 841238, 4 pages http://dx.doi.org/ $10.1155 / 2014 / 841238$.

Todele, A., Haddad, N.I., Malhotra, R. and Samarah, N. (2005). Induced polygenic variability in kabuli chickpea lines. Crop. Research, 29(1): 118-128.

Umair M., Ali S., Bashir K. and Hussein, S. (2010). Evaluation of different seed priming techniques in mung bean (Vigna radiate L.). Soil and Environment, 29(2): PP 181-186.

Venkatasubramanian and Umarani, R. (2007). Evaluation of seed priming methods to improve seed performance of tomato, eggplant and Chilli. Seed Science \& Technology, 35: 487-493.

\section{How to cite this article:}

Ameer Sohail, S., A.K. Chaurasia and Bineeta M. Bara. 2018. Effect of Different Seed Priming Methods on Germination and Vigour of Kabuli Chickpea (Cicer kabulium L.) Seeds. Int.J.Curr.Microbiol.App.Sci. 7(08): 1396-1404. doi: https://doi.org/10.20546/ijcmas.2018.708.160 